\title{
Could Human Leukocyte Antigens (HLA) be Predictive Factors to Interferon Response among Chronic Hepatitis C Virus Hepatitis?
}

\author{
Shaala AY ${ }^{1}$, Harfoush RA ${ }^{1}$, ElKhouly EH ${ }^{2}$, Ahmed MA ${ }^{3}$ and Morsi MG ${ }^{1 *}$ \\ ${ }^{1}$ Department of Medical Microbiology and Immunology, Faculty of medicine, University of Alexandria, Egypt \\ ${ }^{2}$ Department of Tropical, Faculty of medicine, University of Alexandria, Egypt \\ ${ }^{3}$ Department of Clinical Pathology (Hematology), Faculty of medicine, University of Alexandria, Egypt
}

\begin{abstract}
Prevalence of Hepatitis C virus (HCV) in Egypt is 22\% as reported by World Health Organization (WHO) 2012. Interferon (IFN)-based treatments are currently the main therapeutic option. However, depending upon variations in their human leukocyte antigen (HLA), some patients do not respond well to IFN therapy. The current study evaluated some HLA class II alleles among $200 \mathrm{HCV}$ positive individuals from Alexandria, Egypt, who were receiving standard IFN therapy. In this study, 30 patients $(33.3 \%)$ showed a sustained virological response (SVR) to IFN therapy, whereas $30(33.3 \%)$ did not and $30(33.3 \%)$ cleared the virus spontaneously. 30 unrelated healthy volunteers served as controls. DNA was extracted by spin column method from lysed blood of all enrollees for HLA-DRB1 and HLADQB1 allele typing by sequence specific oligonucleotide probe (SSOP), whilst plasma was used for HCV quantitation by real time polymerase chain reaction (RT-PCR) and genotyping by line probe assay INNO LiPA (Innogenetics). HLA-DRB $1{ }^{*} 03$ individually $(p=0.025)$ or in combination HLA-DRB $1{ }^{*} 04(p=0.035)$ revealed to be significant protective alleles against HCV infection. In patients on IFN therapy, HLA-DRB1*11 was significantly associated with viral clearance. In contrast, HLA-DRB1*07 $(p=0.005)$ was associated with viral persistence. We can conclude that certain HLA class II alleles could predict response to IFN therapy as early as possible before starting treatment of chronic $\mathrm{HCV}$ cases and can be used as successful guide to clinicians in deciding the therapeutic regimen for Egyptian patients infected with HCV genotype 4.
\end{abstract}

Keywords: HLA; HCV; IFN; RT- PCR; InnoLiPA; SSOP; Clearance; Persistence

\section{Introduction}

HLAs are encoded by a complex of genes, which are among the most polymorphic regions of the human genome. Allelic variants of HLA have been reported to be involved in immune responses to infectious agents such as (HIV), hepatitis B virus (HBV) and hepatitis $\mathrm{C}$ virus (HCV) [1]. Previously, several HLA alleles have been found to be associated with susceptibility and resistance to HCV infection, pathogenesis leading to liver damage, cirrhosis and the response to IFN therapy but their results were inconsisten [2-4]. Globally an estimated 180 million people, or roughly $3 \%$ of the world's population, are currently infected [5]. The burden of disease is greatest in developing countries: the highest reported prevalence is in Egypt (22\%), China (3.2\%) and Pakistan (4.8\%) as reported by World Health Organization (WHO) [6]. The spectrum of liver disease in patients infected with HCV ranges from minimal lesions in HCV asymptomatic carriers to chronic hepatitis with minimal to severe liver damages, cirrhosis and hepatocellular carcinoma [7]. HCC is third in incidence among the cancer diseases in men, with $>8,000$ new cases predicted by 2012 in this population [6]. The pathogenesis of HCV associated liver disease is believed to be mainly mediated by the immune system [8]. In the host immune reaction against viral infections HLA alleles play a vital role in modulating immune responses [9]. HLA class I and II antigens are central to human immune response and thus ideal candidate genes to investigate for association with HCV outcomes [10]. Various HLA class II alleles have been linked with either persistence or clearance of HCV [11-14]. So, the current study aimed at testing several HLA alleles to detect clearance from persistance ones responsible for failure of treatment. This may aid clinicians in choosing successful line of therapy suitable for each case as early as possible saving money and complications of non responders.

\section{Subjects and Methods}

Our subjects (HCV infected cases) were selected from Alexandria Main University Hospital (Tropical department) and Alexandria Army Forced Main Hospital (Mostafa Kamel). Group I: 30 Spontaneous cleared subjects (SCS), GroupII: 30 Sustained Virologic responders (SVR), Group III: 30 Non responders to Interferon (NR). 30 healthy persons served as controls to immunologic procedures. An informed consent was taken from all enrollees before sampling. Investigations done to all enrollees were; full history taking, clinical examination and the following laboratory tests [15];

i. Complete blood picture using an automated cell counter (sysmex (KX-21 N), Roche, Japan).

ii. Liver function tests (Alanine aminotransferase (ALT), Aspartate aminotransferase (AST), Total bilirubin, albumin, and gamma glutamyl transferase (GGT) using Dimension RxL (Dad Behring Germany).

iii. Detection and quantitation of HCV RNA in sera by real time polymerase chain reaction (RT-PCR).

*Corresponding author: Mona Gamal El Deen Morsi, Faculty of Medicine Department of Medical Microbiology and Immunology, Alexandria, Egypt, Tel: 01005171621; E-mail: morsirg@yahoo.com

Received April 15, 2013; Accepted May 23, 2013; Published May 27, 2013

Citation: Shaala AY, Harfoush RA, ElKhouly EH, Ahmed MA, Morsi MG (2012) Could Human Leukocyte Antigens (HLA) be Predictive Factors to Interferon Response among Chronic Hepatitis C Virus Hepatitis?. J Medical Microbiol Diagnosis S1: 003. doi:10.4172/2161-0703.S1-003

Copyright: (c) 2013 Shaala AY, et al. This is an open-access article distributed under the terms of the Creative Commons Attribution License, which permits unrestricted use, distribution, and reproduction in any medium, provided the original author and source are credited. 
Citation: Shaala AY, Harfoush RA, ElKhouly EH, Ahmed MA, Morsi MG (2012) Could Human Leukocyte Antigens (HLA) be Predictive Factors to Interferon Response among Chronic Hepatitis C Virus Hepatitis?. J Medical Microbiol Diagnosis S1: 003. doi:10.4172/2161-0703.S1-003

Page 2 of 5 USA).

iv. Genotyping of HCV by line probe assay INNO-LiPA (Innogenetics,

v. HLA class II $\left(\mathrm{DRB} 1^{\star} 01^{\star}\right.$-DRB1*15) typing: genomic DNA was extracted from whole blood (after lysis by lysing buffer) using Qiagen spin column QIAamp ${ }^{\circledR}$ DNA Blood Mini Kit. HLA class II alleles were determined at the genotype level with 2 digit intermediate/low resolution. This was performed using INNO-LiPA plus; a line probe assay designed for molecular typing of HLA alleles at the allele group level. The principle of the test was based on reverse hybridization of amplified biotinylated DNA sample which was chemically denatured. Separated strands were hybridized with specific oligonucleotide probes immobilized as parallel lines on membrane-based strips. This was followed by a stringent wash step to remove any mismatched amplified material. After the stringent wash, streptavidin conjugate with alkaline phosphatase was added and bound to any biotinylated hybrid previously formed. Incubation with a substrate solution containing a chromogen resulted in a purple/brown precipitate. The reaction was stopped by a wash step, and the reactivity pattern of the probe was recorded. An amplification kit (INNO-LiPA HLA DRB1*-15 amp Plus) was provided for standardized preparation of biotinylated amplified samples. The amplification kit was based on polymerase chain reaction (PCR). Amplification products were subsequently hybridized using 1 typing strip on which 37 sequence- specific DNA probes and 2 control probes were fixed. The INNO-LiPA HLA plus was designed to give the best possible resolution, at the allele group (this means the first 2 digits after the asterisk in an allele name when following standard HLA nomenclature e.g. HLA-DR $\left.{ }^{\star} 01\right)$.

\section{Data Analysis}

Descriptive statistics included range, mean $\pm \mathrm{SD}$, median, frequencies (number of cases) and percentages when appropriate. Comparisons of numerical variables between the study groups were made using the Mann Whitney $U$ test for independent samples. To compare categorical data, the Chi squared $\left(\chi^{2}\right)$ test was used. When the expected frequency was less than 5, Fisher Exact test was used instead. Accuracy was represented using the terms sensitivity and specificity. Receiver operator characteristic analysis was used to determine the optimum cut off value for the studied tests. Various variables were tested for correlation using the Spearman rank correlation coefficient equation for non-normal variables. $\mathrm{p}$ values less than 0.05 were considered statistically significant. Normality of data was checked by the Kolmogorov Smirnov test. The quantitative data were analyzed using analysis of variables (ANNOVA) test to test for significance then post hoc tukey test was used to compare between 3 studied groups. Our methods violated the normal assumption; therefore, the data were analyzed using non-parametric tests. Two-tailed tests were used where appropriate. All statistical calculations were performed using the computer programs Microsoft Excel 2007 (Microsoft Corporation, NY, and United States) and SPSS (Statistical Package for the Social Sciences; SPSS, USA) version 15 for Microsoft Windows.

\section{Results}

Results are illustrated in the following tables: Table 1 shows base line HCV load among groupII sustained virologic responders (SVR) and group II non responders (NR) which ranged between $\left(<1 \times 10^{6} \mathrm{IU} /\right.$ $\left.\mathrm{ml}-<5 \times 10^{6} \mathrm{IU} / \mathrm{ml}\right)$. SVR were mainly $<1 \times 10^{6} \mathrm{IU} / \mathrm{ml}(46 \%)$ while NR were mainly $<5 \times 10^{6} \mathrm{IU} / \mathrm{ml}(36.5 \%)$ and $\mathrm{p}=0.05^{\star}$ was significant.

Table 2 illustrates hematological data among 3 groups studied;

\begin{tabular}{|c|c|c|c|}
\hline 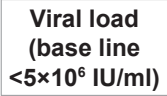 & $\begin{array}{c}\text { Sustained virology } \\
\text { response (no.30) } \\
\text { No. }(\%)\end{array}$ & $\begin{array}{c}\text { Non Responders (no.30) } \\
\text { No. (\%) }\end{array}$ & $\begin{array}{c}\text { Statistics } \\
\text { tests }\end{array}$ \\
\hline$<1 \times 10^{6} \mathrm{IU} / \mathrm{ml}$ & $14(46 \%)$ & $9(30 \%)$ & Chi $=0.05$ \\
\hline$<2 \times 10^{6} \mathrm{IU} / \mathrm{ml}$ & $8(26 \%)$ & $2(8 \%)$ & $p=0.05^{*}$ \\
\hline$<3 \times 10^{6} \mathrm{IU} / \mathrm{ml}$ & $2(8 \%)$ & $2(8 \%)$ & $\mathrm{T}=0.048$ \\
\hline$<4 \times 10^{6} \mathrm{IU} / \mathrm{ml}$ & $3(10 \%)$ & $6(17.5 \%)$ & $P=0.05^{*}$ \\
\hline$\left.<5 \times 10^{6} \mathrm{IU} / \mathrm{ml}\right)$ & $3(10 \%)$ & $11(36.5 \%)$ & $U=111$ \\
\hline Mean \pm SD & $1.725 .775 \pm 1.375 .725 \mathrm{IU} / \mathrm{ml}$ & $3.725 .575 \pm 1.550 .650 \mathrm{IU} / \mathrm{ml}$ & $p=0.05^{\star}$ \\
\hline median & $1.575 .125 \mathrm{IU} / \mathrm{ml}$ & $2.455 .505 \mathrm{IU} / \mathrm{ml}$ & \\
\hline Range & 2.755.770-4.250.055 IU/ml & 4.468.110-5.567.502 IU/ml & \\
\hline
\end{tabular}

Table 1: Base line HCV load among Sustained virology responders and Non responders.

Red blood cells count was not significantly different among the three groups however white blood cells count, platelet count and hemoglobin concentration revealed significant difference between Sontaneous cleared (SCS)/Sustained Virologic Respoders (SVR); $<<0.05$ and Spontaneus cleared/Non responders $\mathrm{p}<0.05$ where Sustained Virologic Respoders were less than spontaneously Cleared group and Non Responders were the least. Prothrombin time (INR) was significantly higher among Sustained Virologic Responders and Non Responders compared to Spontaneuosly Cleared Subjects $(\mathrm{p}<0.05)$. Comparing Sustained Virologic Responders to Non Responders all variables tested were no significant $p>0.05$. As shown in Table 3, liver function tests( Albumin, Total Bilirubin, ALT, AST \& GGT) were significantly higher among SVR and NR compared to SCS $\mathrm{p}<0.05$. While comparing SVR to NR variables were no significant $\mathrm{p}>0.05$. DRB1 ${ }^{\star} 07$ was $90 \%$ among $\mathrm{NR}(\mathrm{p}=0.001)$.

Table 4 shows HLA alleles among the studied subjects. The striking alleles were HLA DRB1 ${ }^{\star} 0385 \%$ and HLA DRB1 ${ }^{\star} 0446.5 \%$ among SCS ( $\mathrm{p}=0.005 \& \mathrm{p}=0.004$ respectively). While SCR revealed $43.5 \%$ and $40 \%$ respectively. NR was $0 \%$ for both alleles. NR revealed $90 \%$ association with HLA DRB ${ }^{\star} 07(\mathrm{p}=0.001)$, the other groups were $0 \%$. HLA DRB ${ }^{\star} 11$ was highly significant 0.001 (53.3\% SCS, $90 \%$ SVR and $3.3 \%$ among NR).

\section{Discussion}

In the current study, we have analyzed HCV clearance or persistence with HLA class II antigens of patients on pegylated Interferon (pegIFN) therapy infected with HCV genotype 4. The HLA $\mathrm{DRB} 1^{\star} 07$ allele was found to be significantly associated with virus persistence, whilst HLA-DRB $1^{\star} 03$, HLA DRB $1^{\star} 04$ and HLA DRB $1^{\star} 11$ were associated with virus clearance. In a comparison of the allelic distribution of the HLA-DRB1 alleles among all subjects a statistically significant association of HLA-DRB ${ }^{\star} 03$ and ${ }^{*} 04$ with the SCS group was observed, indicating a protective advantage towards HCV infection of this allele. As these alleles were not found among non responders, we postulate that these alleles are probably responsible for spontaneous clearance of the virus, in agreement with the previous study of [16] When the HLA allele differences were compared between the SVR and non-SVR groups with the SCS group, no significant association was observed at any locus. However, when the non-SVR group was compared with the SVR group, the HLA-DB1 ${ }^{\star} 03$ allele was found to be associated with virus clearance and HLA-DRB1 ${ }^{\star} 07$ with virus persistence following IFN therapy, the former being consistent with previous findings [12,17-19]. In addition, [9] observed a significantly higher frequency of HLA-DB1 ${ }^{\star} 03$ in patients who spontaneously 
Citation: Shaala AY, Harfoush RA, ElKhouly EH, Ahmed MA, Morsi MG (2012) Could Human Leukocyte Antigens (HLA) be Predictive Factors to Interferon Response among Chronic Hepatitis C Virus Hepatitis?. J Medical Microbiol Diagnosis S1: 003. doi:10.4172/2161-0703.S1-003

Page 3 of 5

\begin{tabular}{|c|c|c|c|c|}
\hline $\begin{array}{l}\text { Variables } \\
\text { tested }\end{array}$ & $\begin{array}{l}\text { Spontaneous Cleared } \\
(n=30)\end{array}$ & $\begin{array}{l}\text { Sustained virologic } \\
\text { response }(n=30)\end{array}$ & $\begin{array}{l}\text { NonResponders } \\
(n=30)\end{array}$ & Statistics/ANOVA \\
\hline \multicolumn{5}{|l|}{$\begin{array}{l}\text { RBCs count } \\
\left(\mathrm{N}=4-5.5 \times 10^{6} / \mathrm{ml}\right)\end{array}$} \\
\hline Mean \pm SD & $4.520 \times 10^{6} / \mathrm{ml} \pm 0.45$ & $4.421 \times 10^{6} / \mathrm{ml} \pm 0.48$ & $4.134 \times 10^{6} / \mathrm{ml} \pm 0.55$ & $F=0.736$ \\
\hline Median & $4.8 \times 10^{6} / \mathrm{ml}$ & $4.6 \times 10^{6} / \mathrm{ml}$ & $4.4 \times 10^{6} / \mathrm{ml}$ & $p=0.157$ \\
\hline Range & $3.8-5.6 \times 10^{6} / \mathrm{ml}$ & $3.7-5.4 \times 10^{6} / \mathrm{ml}$ & $3.6-5.2 \times 10^{6} / \mathrm{ml}$ & \\
\hline \multicolumn{5}{|l|}{ WBCs count } \\
\hline$(\mathrm{N}=4.500-10.000 / \mathrm{ml})$ & & & & $F=75.911, p=0.0001^{*}$ \\
\hline Mean \pm SD & $6.855 \times 10^{3} / \mathrm{ml} \pm 0.45$ & $4.754 \times 10^{3} / \mathrm{ml} \pm 0.34$ & $4.335 \times 10^{3} / \mathrm{ml} \pm 0.58$ & SCS/SVR; $t=9.923 p<0.05^{*}$ \\
\hline Median & $6.8 \times 10^{3} / \mathrm{ml}$ & $4.8 \times 10^{3} / \mathrm{ml}$ & $4.3 \times 10^{3} / \mathrm{ml}$ & SCS/NR; $t=11.172 p<0.05^{*}$ \\
\hline Range & $5.8-7.8 \times 10^{6} / \mathrm{ml}$ & $4.2-5.7 \times 10^{6} / \mathrm{ml}$ & $3.8-5.6 \times 10^{6} / \mathrm{ml}$ & SVR/NR; $t=1.321, p>0.05$ \\
\hline $\begin{array}{l}\text { Hemoglobin } \\
(\mathrm{N}=12-15 \mathrm{~g} / \mathrm{dl})\end{array}$ & & & & $F=7.971, p=0.001^{*}$ \\
\hline Mean \pm SD & $13.22 \mathrm{~g} / \mathrm{dl} \pm 1.25$ & $11.52 \mathrm{~g} / \mathrm{dl} \pm 1.07$ & $11.22 \mathrm{~g} / \mathrm{dl} \pm 1.35$ & SCS/SVR; $t=3.423, p<0.05^{*}$ \\
\hline Median & $13 \mathrm{~g} / \mathrm{dl}$ & $11.6 \mathrm{~g} / \mathrm{dl}$ & $11.2 \mathrm{~g} / \mathrm{dl}$ & SCS/NR; $\mathrm{t}=3.852, \mathrm{p}<0.05^{*}$ \\
\hline Range & $11.5-15.1 \mathrm{~g} / \mathrm{dl}$ & $11.2-13.1 \mathrm{~g} / \mathrm{dl}$ & $11.2-13.3 \mathrm{~g} / \mathrm{dl}$ & SVR/NR; $t=0.351, p>0.05$ \\
\hline $\begin{array}{l}\text { Platelet count } \\
\left(\mathrm{N}=150-450 \times 10^{3} / \mathrm{ml}\right)\end{array}$ & & & & $F=12.171, p=0.001^{*}$ \\
\hline Mean \pm SD & $287 \times 10^{3} / \mathrm{ml} \pm 85$ & $175 \times 10^{3} / \mathrm{ml} \pm 58.7$ & $162 \times 10^{3} / \mathrm{ml} \pm 45.7$ & SCS/SVR; $t=4.043, p<0.05^{*}$ \\
\hline Median & $268 \times 10^{3} / \mathrm{ml}$ & $178 \times 10^{3} / \mathrm{ml}$ & $168 \times 10^{3} / \mathrm{ml}$ & SCS/NR; $\mathrm{t}=4.452, \mathrm{p}<0.05^{*}$ \\
\hline Range & $158-478 \times 10^{6} / \mathrm{ml}$ & $108-278 \times 10^{6} / \mathrm{ml}$ & $105-238 \times 10^{6} / \mathrm{ml}$ & SVR/NR;t=0.451, p>0.05 \\
\hline $\begin{array}{l}\text { Prothrombin } \\
\text { (INR=0.8-1.2) }\end{array}$ & & & & $\mathrm{F}=38.471, \mathrm{P}=0.0001^{*}$ \\
\hline Mean \pm SD & $1.11 \pm 0.130$ & $1.33 \pm 0.120$ & $1.31 \pm 0.035$ & SCS/SVR; $\mathrm{t}=7.420, \mathrm{p}<0.05^{*}$ \\
\hline Median & 0.98 & 1.22 & 1.23 & SCS/NR; $t=7.289, p<0.05^{*}$ \\
\hline Range & $0.85-1.20$ & $1.15-1.35$ & $1.25-1.30$ & SVR/NR ; $t=0.151, p>0.05$ \\
\hline
\end{tabular}

INR; International normalized ratio, ${ }^{*} \mathrm{p}<0.05$ significant

Table 2: Base line Haematological data among studied groups.

\begin{tabular}{|c|c|c|c|c|}
\hline $\begin{array}{l}\text { Variables } \\
\text { tested }\end{array}$ & $\begin{array}{l}\text { Spontaneous } \\
\text { Cleared }(n=30)\end{array}$ & $\begin{array}{l}\text { Sustained virology } \\
\text { response }(n=30)\end{array}$ & $\begin{array}{l}\text { Non Responders } \\
\text { (no.30) }\end{array}$ & Statistics ANNOVA \\
\hline $\begin{array}{l}\text { Albumin } \\
(\mathrm{N}=3.5-5.3 \mathrm{~g} / \mathrm{dl})\end{array}$ & & & & $\mathrm{F}=5.471, \mathrm{P}=0.007^{*}$ \\
\hline Mean \pm SD & $4.200 \mathrm{~g} / \mathrm{dl} \pm 0.452$ & $3.754 \mathrm{~g} / \mathrm{dl} \pm 0.456$ & $3.667 \mathrm{~g} / \mathrm{dl} \pm 0.375$ & SCS/SVR; $\mathrm{t}=2.564, \mathrm{p}<0.05^{*}$ \\
\hline Median & $4.5 \mathrm{~g} / \mathrm{dl}$ & $3.8 \mathrm{~g} / \mathrm{dl}$ & $3.9 \mathrm{~g} / \mathrm{dl}$ & SCS/NR; $t=2.893, p<0.05^{*}$ \\
\hline Range & $3.7-5.3 \mathrm{~g} / \mathrm{dl}$ & $3.2-4.9 \mathrm{~g} / \mathrm{dl}$ & $3.3-4.3 \mathrm{~g} / \mathrm{dl}$ & SVR/NR ; t=0.257, $p>0.05$ \\
\hline $\begin{array}{l}\text { Total Bilirubin } \\
(\mathrm{N}=0.2-1.2 \mathrm{~g} / \mathrm{dl})\end{array}$ & & & & $\mathrm{F}=15.071, \mathrm{P}=0.0001^{*}$ \\
\hline Mean \pm SD & $0.540 \mathrm{mg} / \mathrm{dl} \pm 0.226$ & $1.517 \mathrm{mg} / \mathrm{dl} \pm 0.675$ & $1.540 \mathrm{mg} / \mathrm{dl} \pm 0.696$ & SCS/SVR; $\mathrm{t}=4.410, \mathrm{p}<0.05^{*}$ \\
\hline Median & $0.5 \mathrm{mg} / \mathrm{dl}$ & $1.53 \mathrm{mg} / \mathrm{dl}$ & $1.75 \mathrm{mg} / \mathrm{dl}$ & SCS/NR; $t=6.219, p<0.05^{*}$ \\
\hline Range & $0.3-1.3 \mathrm{mg} / \mathrm{dl}$ & $0.4-2.5 \mathrm{mg} / \mathrm{dl}$ & $0.4-2.6 \mathrm{mg} / \mathrm{dl}$ & SVR/NR ; $t=0.341, p>0.05$ \\
\hline ALT (9-40 IU/L) & & & & $\mathrm{F}=287.771, \mathrm{P}=0.0001^{*}$ \\
\hline Mean \pm SD & $27.90 \mathrm{IU} / \mathrm{ml} \pm 4.22$ & $75.000 \mathrm{IU} / \mathrm{ml} \pm 8.17$ & $73.15 \mathrm{IU} / \mathrm{ml} \pm 5.29$ & SCS/SVR; $\mathrm{t}=20.4, \mathrm{p}<0.05^{*}$ \\
\hline Median & $28 \mathrm{IU} / \mathrm{ml}$ & $78 \mathrm{IU} / \mathrm{ml}$ & $73 \mathrm{IU} / \mathrm{ml}$ & SCS/NR; $\mathrm{t}=20.2, \mathrm{p}<0.05^{*}$ \\
\hline Range & $21-36 \mathrm{IU} / \mathrm{ml}$ & 55-86 IU/ml & $55-84 \mathrm{IU} / \mathrm{ml}$ & SVR/NR ; $t=0.651, p>0.05$ \\
\hline AST (10-35 IU/L) & & & & $\mathrm{F}=347.791, \mathrm{P}=0.0001^{*}$ \\
\hline Mean \pm SD & $22.45 \mathrm{IU} / \mathrm{ml} \pm 4.75$ & $67.48 \mathrm{IU} / \mathrm{ml} \pm 5.65$ & $69.95 \mathrm{IU} / \mathrm{ml} \pm 5.92$ & SCS/SVR;t=20.713,p<0.05* \\
\hline Median & $24 \mathrm{IU} / \mathrm{ml}$ & $69 \mathrm{IU} / \mathrm{ml}$ & $66 \mathrm{IU} / \mathrm{ml}$ & SCS/NR; $\mathrm{t}=20.223, \mathrm{p}<0.05^{*}$ \\
\hline Range & $12-35 \mathrm{IU} / \mathrm{ml}$ & $56-72 \mathrm{IU} / \mathrm{ml}$ & $58-78 \mathrm{IU} / \mathrm{ml}$ & SVR/NR ; t $=0.752, p>0.05$ \\
\hline GGT (0-42 IU/L) & & & & $\mathrm{F}=53.271, \mathrm{P}=0.0001^{*}$ \\
\hline Mean \pm SD & $20.75 \mathrm{IU} / \mathrm{ml} \pm 6.55$ & $47.34 \mathrm{IU} / \mathrm{ml} \pm 8.56$ & $48.70 \mathrm{IU} / \mathrm{ml} \pm 7.25$ & SCS/SVR; $\mathrm{t}=8.821, \mathrm{p}<0.05^{*}$ \\
\hline Median & $21 \mathrm{IU} / \mathrm{ml}$ & $48 \mathrm{IU} / \mathrm{ml}$ & $49 \mathrm{IU} / \mathrm{ml}$ & SCS/NR; $t=9.266, p<0.05^{*}$ \\
\hline Range & $9-36 \mathrm{IU} / \mathrm{ml}$ & 29-59 IU/ml & $37-60 \mathrm{IU} / \mathrm{ml}$ & SVR/NR ; $t=0.571, p>0.05$ \\
\hline
\end{tabular}

ALT; Alanine aminotransferase, AST; Aspartate aminotransferase

GGT; Gammaglutamyl transferase. ${ }^{*}=p<0.05$ is significant.

Table 3: Base line Liver Function tests of studied cases.

cleared the virus as opposed to chronically infected patients, although we did not see any statistically significant difference in the frequency of this allele in patients and normal controls. However, when the effect of IFN therapy in patients was analyzed, we observed a statistically higher frequency of this allele in SVR patients compared with non-SVR patients. This association is consistent with the observations of [12] although they did not report the HCV genotype, it was most probably genotype 1, which is the most prevalent in UK patients. In contrast to 
Citation: Shaala AY, Harfoush RA, ElKhouly EH, Ahmed MA, Morsi MG (2012) Could Human Leukocyte Antigens (HLA) be Predictive Factors to Interferon Response among Chronic Hepatitis C Virus Hepatitis?. J Medical Microbiol Diagnosis S1: 003. doi:10.4172/2161-0703.S1-003

\begin{tabular}{|c|c|c|c|c|}
\hline HLA alleles & $\begin{array}{l}\text { Spontaneous } \\
\text { Cleared } \\
(n=30)\end{array}$ & $\begin{array}{l}\text { Sustained } \\
\text { virology } \\
\text { response }(n=30)\end{array}$ & $\begin{array}{l}\text { Non } \\
\text { Responders } \\
\text { (no.30) }\end{array}$ & $\begin{array}{l}\text { P of Fisher } \\
\text { exact test }\end{array}$ \\
\hline HLA DRB1* 01 & $1(3.3 \%)$ & $1(3.3 \%)$ & $3(9.9 \%)$ & 0.324 \\
\hline HLA DRB1* 02 & $1(3.3 \%)$ & $1(3.3 \%)$ & $2(6.6 \%)$ & 0.456 \\
\hline HLA DRB ${ }^{*} 03$ & $26(85 \%)$ & $13(43.5 \%)$ & $0(0 \%)$ & $0.005^{*}$ \\
\hline HLA DRB ${ }^{*} 04$ & $14(46.5 \%)$ & $12(40 \%)$ & $0(0 \%)$ & $0.004^{*}$ \\
\hline HLA DRB $1 * 05$ & $1(3.3 \%)$ & $1(3.3 \%)$ & $10(33.3 \%)$ & 0.260 \\
\hline HLA DRB1* 06 & $1(3.3 \%)$ & $1(3.3 \%)$ & $1(3.3 \%)$ & 0.800 \\
\hline HLA DRB1* 07 & $0(0 \%)$ & $0(0 \%)$ & $27(90 \%)$ & $0.001^{*}$ \\
\hline HLA DRB1* 08 & $2(6.6 \%)$ & $1(3.3 \%)$ & $2(6.6 \%)$ & 0.732 \\
\hline HLA DRB1* 09 & $1(3.3 \%)$ & $1(2.5 \%)$ & $3(9.9 \%)$ & 0.160 \\
\hline HLA DRB1* 10 & $1(3.3 \%)$ & $1(2.5 \%)$ & $2(6.6 \%)$ & 0.345 \\
\hline HLA DRB1* 11 & $16(53.3 \%)$ & 27 (90\%) & $1(3.3 \%)$ & $0.001^{*}$ \\
\hline HLA DRB1* 12 & $1(3.3 \%)$ & $1(2.5 \%)$ & $2(6.6 \%)$ & 0.123 \\
\hline HLA DRB1* 13 & $1(3.3 \%)$ & $1(2.5 \%)$ & $3(9.9 \%)$ & 0.234 \\
\hline HLA DRB1* 14 & $2(6.6 \%)$ & $1(2.5 \%)$ & $2(6.6 \%)$ & 0.546 \\
\hline HLA DRB1* 15 & $2(6.6 \%)$ & $0(0 \%)$ & $2(6.6 \%)$ & 0.675 \\
\hline
\end{tabular}

${ }^{*} \mathrm{p}<0.05$ significant

Table 4: Frequency of HLA DRB*1-15 alleles among studied cases (SCS, SVR, NR).

our study population, which consisted of genotype 4 only, while the most common genotype in Pakistan was 3a [20,21]. These observations are interesting as they indicate a possible mechanism in which the HLA-DB1*03 and 04 alleles are somehow involved in clearance of virus from patients spontaneously by natural immunity or by an IFNsupplemented immune system. However, it must be pointed out that this virus clearance following IFN treatment might be dependent on viral genotype [22]. We may say that our HLA-DB1 ${ }^{\star} 03,{ }^{*} 04$ patients infected with HCV genotype 4 may not have spontaneously cleared the virus, but they did clear the virus following IFN therapy. In the present study, the HLA-DRB $1^{\star} 07$ allele was found to be associated with disease persistence even after IFN therapy, which is consistent with the results of [23] who also observed a higher prevalence of HLA-DRB1 ${ }^{\star} 07$ in non-SVR compared with SVR patients. This could be due to the fact that their patients were mostly infected with genotype 2. For HLADRB ${ }^{\star} 11$, we also observed a qualitatively similar result to that for the HLA-DB $1^{\star} 03$ allele, but this became statistically non-significant once the Bonferroni correction was applied. Linkage disequilibrium results showed that HLA-DRB $1^{\star} 11$ is appearing as a significant allele because of its linkage to the HLA-DB $1^{*} 03$ allele [24]. Observed that patients with the HLA-DRB1 ${ }^{\star} 11$ allele cleared the virus more effectively, and this remained statistically significant even after correction for multiple testing. Similar results have been reported in various other studies [25,26]. It is worth mentioning that the HENCORE group did not see any significant association (after Bonferroni correction) between any MHC class II allele and the response of patients to IFN therapy [27]. This again could be due to population ethnic differences [28] showed to be derived from Middle Eastern, Central Asian and European populations. Other investigators previously worked [29] revealed a statistically significant association of the haplotype HLA-DRB $1^{\star} 07$, DB1 ${ }^{\star} 05$ with persistence of disease. Non-responders (non-SVR) had this haplotype (05) at almost ten times the frequency of responders (SVR).This is an important finding as, to date, we have not come across any report that has demonstrated the association of an HLA-DRB1 allele with persistence of HCV among Egyptian patients. However, Fanning et al. [3] reported a positive response to IFN therapy in patients from Ireland with the haplotype HLA-DRB ${ }^{\star} 07$, again indicating the need to conduct such studies in ethnically different patient populations. In agreement with the data of [30], we also found this haplotype to be the most common in non-responders in their population studied. Our findings may have important implications for disease management of patients suffering from HCV infection in Egypt, as in the case of other studies [22]. We also observed that the host immune system played an important role in virus clearance, which was probably viral genotype dependent. However, in contrast to the work of Jiao and Wang [22], who found a higher response rate to IFN in patients with the HLA$\mathrm{DRB} 1^{\star} 07$ allele, we found that in our population these patients were unable to clear the virus. This is important for disease management, as the normal clinical practice in Egypt is that patients are treated with peg IFN therapy, so if HLA typing of these patients was performed before the start of therapy and an allele or haplotype associated with persistence was found, these patients could be given other therapy from the start saving money and complications of non responding ones. Our study is valid for poor countries where patients cannot afford expensive therapies. We can conclude that data generated from our study may be helpful in future for clinicians to predict treatment outcome of their cases. We emphasize the importance of the use of pharmacogenomic data in patients' treatment in poor countries, who can ill afford expensive treatment with a negative outcome.

\section{Acknowledgment}

We would like to acknowledge Alexandria Main Armed Forces Hospital and Alexandria Faculty of Medicine, Egypt who sponsored materials and equipment used in our current study.

\section{References}

1. Singh R, Kaul R, Kaul A, Khan K (2007) A comparative review of HLA associations with hepatitis $B$ and $C$ viral infections across global populations. World J Gastroenterol 13: 1770-1787.

2. Sinn DH, Paik SW, Kang P, Kil JS, Park SU, et al. (2008) Disease progression and the risk factor analysis for chronic hepatitis C. Liver Int 28: 1363-1369.

3. Fanning LJ, Kenny-Walsh E, Shanahan F (2004) Persistence of hepatitis C virus in a white population: associations with human leukocyte antigen class 1 . Hum Immunol 65: 745-751.

4. Ali L, Mansoor A, Ahmad N, Siddiqi S, Mazhar K, et al. (2010) Patient HLA-DRB1 and $-\mathrm{DQB} 1^{*}$ allele and haplotype association with hepatitis $\mathrm{C}$ virus persistence and clearance. J Gen Virol 91: 1931-1938.

5. Lavanchy D (2011) Evolving epidemiology of hepatitis C virus. Clin Microbio Infect 17: 107-115.

6. Ford N, Kirby C, Singh K, Mills EJ, Cooke G, et al. (2012) Chronic hepatitis C treatment outcomes in low- and middle-income countries: a systematic review and meta-analysis. Bull World Health Organ 90: 540-550.

7. Anwar WA, Khaled HM, Amra HA, El-Nezami H, Loffredo CA (2008) Changing pattern of hepatocellular carcinoma $(\mathrm{HCC})$ and its risk factors in Egypt possibilities for prevention. Mutat Res 659: 176-184

8. Deuffic-Burban S, Mohamed MK, Larouze B, Carrat F, Valleron AJ (2006) Expected increase in hepatitis C-related mortality in Egypt due to pre-2000 infections. J Hepatol 44: 455-461.

9. Ishii S, Koziel MJ (2008) Immune responses during acute and chronic infection with hepatitis C virus. Clin Immunol 128: 133-147.

10. Tripathy AS, Shankarkumar U, Chadha MS, Ghosh K, Arankalle VA (2009) Association of HLA alleles with hepatitis C infection in Maharashtra, western India. Indian J Med Res 130: 550-555.

11. Harris RA, Sugimoto K, Kaplan DE, Ikeda F, Kamoun M, et al. (2008) Human leukocyte antigen class II associations with hepatitis $C$ virus clearance and virus-specific CD4 T cell response among Caucasians and African Americans. Hepatology 48: 70-79.

12. Hong X, Yu RB, Sun NX, Wang B, Xu YC, et al. (2005) Human leukocyte antigen class II DQB1*0301, DRB1*1101 alleles and spontaneous clearance of hepatitis C virus infection: a meta-analysis. World J Gastroenterol 11: 7302-7307. 
Citation: Shaala AY, Harfoush RA, ElKhouly EH, Ahmed MA, Morsi MG (2012) Could Human Leukocyte Antigens (HLA) be Predictive Factors to Interferon Response among Chronic Hepatitis C Virus Hepatitis?. J Medical Microbiol Diagnosis S1: 003. doi:10.4172/2161-0703.S1-003

13. McKiernan SM, Hagan R, Curry M, McDonald GS, Kelly A, et al. (2004) Distinct MHC class I and II alleles are associated with hepatitis C viral clearance, originating from a single source. Hepatology 40: 108-114.

14. Scotto G, Fazio V, D’Alessandro G, Monno L, Saracino A, et al. (2003) Association between HLA class II antigens and hepatitis $C$ virus infection. J Biol Regul Homeost Agents 17: 316-321.

15. Burrin DH (1986) Immunochemical technique. In: Wilson K \& Goulding KH. A Biologist's Guide to Principles and Techniques of Practical Biochemistry (3 rd ed) Great Britain: Edward Arnold: 141-6.

16. Cramp ME, Carucci $P$, Underhill J, Naoumov NV, Williams R, et al. (1998) Association between HLA class II genotype and spontaneous clearance of hepatitis C viraemia. J Hepatol 29: 207-213.

17. Cursino-Santos JR, Donadi EA, Martinelli AL, Louzada-Junior P, Martinez-Rossi NM (2007) Evolution of hepatitis C virus infection under host factor influence in an ethnically complex population. Liver Int 27: 1371-1378.

18. Thio CL, Thomas DL, Goedert JJ, Vlahov D, Nelson KE, et al. (2001) Racial differences in HLA class II associations with hepatitis C virus outcomes. J Infect Dis 184: 16-21.

19. Yee LJ (2004) Host genetic determinants in hepatitis C virus infection. Genes Immun 5: 237-245.

20. Harcourt G, Hellier S, Bunce M, Satsangi J, Collier J, et al. (2001) Effect of HLA class II genotype on T helper lymphocyte responses and viral control in hepatitis C virus infection. J Viral Hepat 8: 174-179.

21. Idrees M, Riazuddin S (2008) Frequency distribution of hepatitis C virus genotypes in different geographical regions of Pakistan and their possible routes of transmission. BMC Infect Dis 8: 69.
22. Jiao J, Wang JB (2005) Hepatitis C virus genotypes, HLA-DRB alleles and their response to interferon-alpha and ribavirin in patients with chronic hepatitis $C$ Hepatobiliary Pancreat Dis Int 4: 80-83.

23. Alric L, Izopet J, Fort M, Vinel JP, Fontenelle P, et al. (1999) Study of the association between major histocompatibility complex class II genes and the response to interferon alpha in patients with chronic hepatitis $\mathrm{C}$ infection. Hum Immunol 60: 516-523.

24. Minton EJ, Smillie D, Neal KR, Irving WL, Underwood JC, et al. (1998) Association between MHC class II alleles and clearance of circulating hepatitis C virus. Members of the Trent Hepatitis C Virus Study Group. J Infect Dis 178: 39-44.

25. Tillmann HL, Chen DF, Trautwein C, Kliem V, Grundey A, et al. (2001) Low frequency of HLA-DRB1*11 in hepatitis $C$ virus induced end stage liver disease. Gut 48: 714-718.

26. Yenigün A, Durupinar B (2002) Decreased frequency of the HLA-DRB1*11 allele in patients with chronic hepatitis C virus infection. J Virol 76: 1787-1789.

27. Thursz M, Yallop R, Goldin R, Trepo C, Thomas HC (1999) Influence of MHC class II genotype on outcome of infection with hepatitis $\mathrm{C}$ virus. The HENCORE group. Hepatitis C European Network for Cooperative Research. Lancet 354 2119-2124.

28. Reich D, Thangaraj K, Patterson N, Price AL, Singh L (2009) Reconstructing Indian population history. Nature 461: 489-494.

29. Qamar R, Ayub Q, Mohyuddin A, Helgason A, Mazhar K, et al. (2002) Y-chromosomal DNA variation in Pakistan. Am J Hum Genet 70: 1107-1124.

30. Correa PA, Whitworth WC, Kuffner T, McNicholl J, Anaya JM (2002) HLA-DR and DQB1 gene polymorphism in the North-western Colombian population. Tissue Antigens 59: 436-439.
This article was originally published in a special issue, Bacterial Pathogenecity \& Epidemiology handled by Editor. Dr. Morabito Stefano, National Institute of Health, Italy 